\title{
Front Matter: Volume 10667
}

, "Front Matter: Volume 10667," Proc. SPIE 10667, Dimensional Optical Metrology and Inspection for Practical Applications VII, 1066701 (3 August 2018); doi: 10.1117/12.2502239

SPIE Event: SPIE Commercial + Scientific Sensing and Imaging, 2018, Orlando, FL, United States 


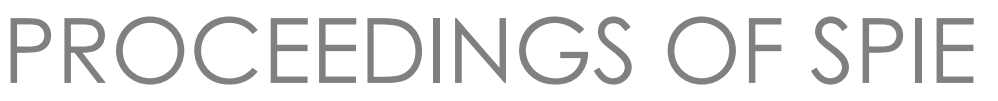

\section{Dimensional Optical Metrology and Inspection for Practical Applications VII}

Kevin G. Harding

Song Zhang

Editors

17-19 April 2018

Orlando, Florida, United States

Sponsored and Published by

SPIE 
The papers in this volume were part of the technical conference cited on the cover and title page. Papers were selected and subject to review by the editors and conference program committee. Some conference presentations may not be available for publication. Additional papers and presentation recordings may be available online in the SPIE Digital Library at SPIEDigitalLibrary.org.

The papers reflect the work and thoughts of the authors and are published herein as submitted. The publisher is not responsible for the validity of the information or for any outcomes resulting from reliance thereon.

Please use the following format to cite material from these proceedings:

Author(s), "Title of Paper," in Dimensional Optical Metrology and Inspection for Practical Applications VII, edited by Kevin G. Harding, Song Zhang, Proceedings of SPIE Vol. 10667 (SPIE, Bellingham, WA, 2018) Seven-digit Article CID Number.

ISSN: 0277-786X

ISSN: 1996-756X (electronic)

ISBN: 9781510618459

ISBN: 9781510618466 (electronic)

Published by

SPIE

P.O. Box 10, Bellingham, Washington 98227-0010 USA

Telephone +1 3606763290 (Pacific Time) · Fax +1 3606471445

SPIE.org

Copyright (C) 2018, Society of Photo-Optical Instrumentation Engineers.

Copying of material in this book for internal or personal use, or for the internal or personal use of specific clients, beyond the fair use provisions granted by the U.S. Copyright Law is authorized by SPIE subject to payment of copying fees. The Transactional Reporting Service base fee for this volume is $\$ 18.00$ per article (or portion thereof), which should be paid directly to the Copyright Clearance Center (CCC), 222 Rosewood Drive, Danvers, MA 01923. Payment may also be made electronically through CCC Online at copyright.com. Other copying for republication, resale, advertising or promotion, or any form of systematic or multiple reproduction of any material in this book is prohibited except with permission in writing from the publisher. The CCC fee code is 0277$786 \mathrm{X} / 18 / \$ 18.00$.

Printed in the United States of America.

Publication of record for individual papers is online in the SPIE Digital Library.

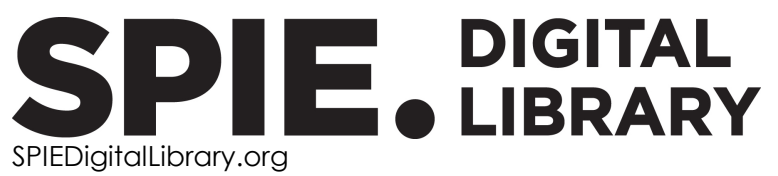

Paper Numbering: Proceedings of SPIE follow an e-First publication model. A unique citation identifier (CID) number is assigned to each article at the time of publication. Utilization of CIDs allows articles to be fully citable as soon as they are published online, and connects the same identifier to all online and print versions of the publication. SPIE uses a seven-digit CID article numbering system structured as follows:

- The first five digits correspond to the SPIE volume number.

- The last two digits indicate publication order within the volume using a Base 36 numbering system employing both numerals and letters. These two-number sets start with $00,01,02,03,04$, 05, 06, 07, 08, 09, 0A, OB ... 0Z, followed by 10-1Z, 20-2Z, etc. The CID Number appears on each page of the manuscript. 


\title{
Contents
}

\author{
$\checkmark \quad$ Authors \\ vii Conference Committee
}

\section{OPTICAL METROLOGY ANALYSIS}

1066702 2D and 3D computational optical imaging using deep convolutional neural networks (DCNNs) [10667-1]

1066704 3D shape measurement by thermal fringe projection: optimization of infrared (IR) projection parameters [10667-3]

1066707 Motion-induced error compensation for 3D shape measurement with phase shifting technique [10667-6]

OPTICAL METROLOGY METHODS I

1066709 Optimal carrier frequency selection for high-speed 3D shape measurement with doublepattern pulse width modulation techniques [10667-8]

10667 OA High-speed 3D shape measurement by GOBO projection of aperiodic sinusoidal fringes: a performance analysis [10667-9]

\section{OPTICAL METROLOGY METHODS II}

10667 OC Recent research on high-resolution 3D range geometry compression (Invited Paper) [10667-10]

10667 OD 3D shape measurement of glass and transparent plastics with a thermal 3D system in the midwave infrared [10667-11]

10667 OE Improved line of light measurements on shiny and transparent surfaces [10667-12]

10667 OF Generation and evaluation of hyperspectral 3D surface models based on a structured light system with hyperspectral snapshot mosaic sensors [10667-13]

\section{OPTICAL METROLOGY APPLICATIONS}

10667 OG Superfast high-resolution dynamic 3D strain measurement of robotic flapping wings [10667-14]

$10667 \mathrm{OH} \quad$ Measurement of creep strain in polymers by means of electronic speckle pattern shearing interferometry [10667-15] 
10667 Ol Hand portable 3D mapper applied to pit quantification on aerospace parts [10667-16]

ADDITIVE METHODS FOR MICRO ELECTRONIC OR FLEXIBLE FEATURES

10667 OK Error mapping method for multi-axis additive manufacturing system [10667-17]

10667 OM Silver nanoparticle electrospray laser deposition for additive manufacturing of microlayers on rigid or flexible substrates [10667-19]

ADVANCED ADDITIVE MANUFACTURING METHODS

1066700 Structured light as an enhancement tool for low contrast features in additive manufacturing [10667-23] 


\title{
Authors
}

Numbers in the index correspond to the last two digits of the seven-digit citation identifier (CID) article numbering system used in Proceedings of SPIE. The first five digits reflect the volume number. Base 36 numbering is employed for the last two digits and indicates the order of articles within the volume. Numbers start with 00, 01, 02, 03, 04, 05, 06, 07, 08, 09, 0A, 0B...0Z, followed by 10-12, 20-2Z, etc.

\author{
Barragán-Pérez, Omar, $\mathrm{OH}$ \\ Brahm, Anika, 04, OD \\ Bromberg, Vadim, OK \\ Castillo, Eduardo A., OM \\ Dietrich, Patrick, OA \\ Fiorillo, Timothy, OK \\ Harding, Kevin, OE, OI, OK, $0 \mathrm{O}$ \\ Heist, Stefan, 04, OA, OD, OF \\ Kar, Aravinda, OM \\ Kühmstedt, Peter, 04, OA, OD, OF \\ Kumar, Ranganathan, $O M$ \\ Landmann, Martin, 04, OA, OD \\ Li, Beiwen, OG \\ Liu, Ziping, 07 \\ McDermed, Shawn, ol \\ Michtchenko, Alexandre, $\mathrm{OH}$ \\ Nehmetallah, George, 02 \\ Nguyen, Thanh, 02 \\ Notni, Gunther, 04, OA, OD, OF \\ Novak, Erik, $\mathrm{Ol}$ \\ Pascual-Francisco, Juan Benito, $\mathrm{OH}$ \\ Ramamurthy, Rajesh, OK \\ Reichwald, Karl, OF \\ Schindwolf, Simon, 04, OD \\ Susarrey-Huerta, Orlando, $\mathrm{OH}$ \\ Wang, Yajun, 09 \\ Zhang, Chen, OF \\ Zhang, Song, 07, 09, 0C
}


Proc. of SPIE Vol. 10667 1066701-6

Downloaded From: https://www.spiedigitallibrary.org/conference-proceedings-of-spie on 26 Apr 2023 Terms of Use: https://www.spiedigitallibrary.org/terms-of-use 


\title{
Conference Committee
}

\author{
Symposium Chair
}

Robert Fiete, Harris Corporation (United States)

Symposium Co-chair

Jay Kumler, JENOPTIK Optical Systems, LLC (United States)

Conference Chairs

Kevin G. Harding, Optical Metrology Solutions (United States)

Song Zhang, Purdue University (United States)

Conference Program Committee

Motoharu Fujigaki, University of Fukui (Japan)

Khaled J. Habib, Kuwait Institute for Scientific Research (Kuwait)

Damien P. Kelly, Technische Universität Ilmenau (Germany)

Peter Kühmstedt, Fraunhofer-Institut für Angewandte Optik und Feinmechanik (Germany)

Beiwen Li, lowa State University (United States)

Rongguang Liang, College of Optical Sciences, The University of Arizona (United States)

Georges T. Nehmetallah, The Catholic University of America (United States)

Gunther Notni, Fraunhofer-Institut für Angewandte Optik und Feinmechanik (Germany)

Lei Tian, Boston University (United States)

Joseph D. Tobiason, Micro Encoder Inc. (United States)

Zhaoyang Wang, The Catholic University of America (United States)

Jiangtao Xi, University of Wollongong (Australia)

\section{Session Chairs}

1 Optical Metrology Analysis

Song Zhang, Purdue University (United States)

2 Optical Metrology Methods I

Maik Rosenberger, Technische Universität Ilmenau (Germany)

3 Optical Metrology Methods II

Kevin G. Harding, Optical Metrology Solutions (United States) 
4 Optical Metrology Applications

Song Zhang, Purdue University (United States)

5 Additive Methods for Micro Electronic or Flexible Features

Kevin G. Harding, Optical Metrology Solutions (United States)

$6 \quad$ Advanced Additive Manufacturing Methods

Kevin G. Harding, Optical Metrology Solutions (United States) 